\title{
BALANCED SCORECARD IN MANAGEMENT ACCOUNTING AND ITS APPLICATION TO INSURANCE COMPANIES IN TURKEY
}

DOI: 10.17261/Pressacademia.2017.689

JEFA- V.4-ISS.3-2017(1)-p.215-223

Ilhan Ege ${ }^{1}$, Zeynep Sener ${ }^{2}$

${ }^{1}$ Mersin University, Department of Economics and Administrative Sciences, Mersin, Turkey. ilhanege@mersin.edu.tr

${ }^{2}$ Mersin University, Department of Economics and Administrative Sciences, Mersin, Turkey. zeynepgizer@mersin.edu.tr

\section{To cite this document}

Ege, I., Sener, Z. (2017). Balanced scorecard in management accounting and its application to insurance companies in Turkey. Journal of Economics, Finance and Accounting (JEFA), V.4, Iss.3, p.215-223.

Permemant link to this document: http://doi.org/10.17261/Pressacademia.2017.689

Copyright: Published by PressAcademia and limited licenced re-use rights only.

\begin{abstract}
Purpose - This paper examines the insurance companies' (in Turkey) opinions regarding balanced scorecards and techniques they used to measure performance.

Methodology - A questionnaire form primary was sent to the Association of the Insurance and Reinsurance Companies in Turkey to identify sub-criteria to be used four perspectives of balanced scorecard. 41 experts responded to the questionnaire. In accordance with the data, another questionnaire was prepared to determine performance measurement, perspectives, criteria and balanced scorecard. Then the second questionnaire was sent to 43 companies (excluding pension companies because of different criteria). 30 companies responded to the questionnaire. The data about opinion of performance measurement and balanced scorecard were analyzed by using SPSS. However, the data about performance criteria, perspectives were analyzed by Analytical Hierarchy Process. For this analyze, we used the geometric mean of 30 companies.

Findings- Findings indicate that insurance companies (66.7\%) prefer balanced scorecard as a tool for performance measurement. It is observed that customer and financial perspectives were found to be the most highlighted perspectives than other ones, internal business processes and learning-growth perspectives, among performance perspectives utilized. Besides, two insurance companies use 'competence perspective' in addition to the four perspectives in their balanced scorecard.

Conclusion- Insurance companies can make use of these criteria to improve their performance and work more effectively by elaborating the criteria which reduce their performance. In this way, as they improve their performance, they can contribute to the economy, especially the finance sector.
\end{abstract}

Keywords: Firm performance, management accounting, balanced scorecard, AHP, insurance companies. JEL Codes: M40, M41, M49

\section{INTRODUCTION}

Today, all businesses have specific objectives of foundation. Foremost among them is to maximize their firm value. In order to achieve their objectives, the businesses need to organize activities to drive performance. However, in that case, decisions made are dominated by a particular understanding of perspective.

The understanding of perspective for business management appears to be a process which has continuously evolved and developed from the past to present. Considering this process, it is observed that some performance approaches have lost their significance while some others come into prominence or new approaches emerge. There has been a shift from a management perspective which strives to attain high profit and the maximum production at the lowest cost to a new management perspective aiming at 'an organization of the future' which emphasizes different criteria such as customer satisfaction and quality in order to be competitive (Akal, 2000, p.5). 
Thanks to new management approaches to be followed in organizations, it is supposed that organizational performance will be improved and thrived. This positive improvement in the performance will strengthen the business by providing a competitive advantage both within and outside the organization. As a result, it is observed in the last twenty-five years that theoretical and practical studies focusing on organizational performance were carried out (Jing and Avery, 2008, p. 67).

Performance measurement indicates to what extent the businesses attain their predetermined targets (Bayrakdaroğlu and Ege, 2007, p.95). The main reason for the increased prevalence to use a performance management system is the purpose to monitor the organization, which traditional accounting systems do not allow (Chytas, Glykas, and Valiris, 2011, p.1).

In the 1980s and early 1990s, performance measurement began to be critically approached. Within this period, financial measures were restricted since they were observed to be inadequate or insufficient in performance development. Additionally, some new accounting methods were developed to regulate the performance of the organizations (Metawie and Gilman, 2005, p.4). These new accounting methods are modern performance measurement methods which additionally use non-financial performance measures to complement the deficiencies of financial measurement. This led to management accounting.

Considering the last twenty-five years, it is observed that the progress in information technologies seems to threaten the sustainability of the businesses owing to the fact that more competitive markets and different organizational structures emerge in this process. Therefore; a company's need to obtain a management accounting and control system increased over time (Kallunki and Silvola, 2008, p.62).

Until the last 15-20 years, businesses used to measure their corporate performance by means of some indicators such as the profit, cash flow derived from balance sheet, income and cash-flow statements. However; as a result of concepts such as change and development in customers, intellectual capital, brand value and human resources, those financial measures regarding previous operating periods were found to be inadequate to measure the real values and performances of businesses (Utkutuğ, 2008, p.56). Along with that, as the service sector and global competition increase in importance the requirement for alternative control and performance measures has also increased (Davis and Albright, 2004, p.136). In order to eliminate this need, it has been stated that the financial and non-financial criteria together should be in balance, and the concept of 'balanced scorecard' has emerged (Yenice, 2007, p.97). In this context, balanced scorecard has aroused interest by both scientists and managers (Ahn, 2001, p.441). In balanced scorecard, financial measures used to measure current performance of the firm indicate the results of the activities realized while non-financial measures are used to measure future performance (Kaplan and Norton, 1992, p.7; Leung, Lam and Cao, 2006, p.682).

The objectives to utilize the strategy-focused balanced scorecard are as follows (Kaplan and Norton, 1996a, p.85):

1. To clarify and update the strategy

2. To communicate strategy throughout the company

3. To align unit and individual goals together with the strategy

4. To link strategic objectives to long-term targets and annual budgets

5. To identify and align strategic initiatives

6. To conduct periodic performance reviews to learn about and improve the strategy.

Kaplan and Norton first carried out a study on the balanced scorecard in twelve companies for one-year period. In the light of the findings was constructed a balanced scorecard which presented criteria for senior managers and provided an overall comprehensive perspective of the business (Kaplan and Norton, 1992, p.71). In 1996, they juxtaposed the balanced scorecard to the business strategy; thus, strategic objectives were converted to tangible criteria. In 2001, however, they placed the strategy to the focal point of the management process in order to provide competitive advantage and increase the effectiveness through change management (Braam and Nijsen, 2004, p.338; Asosheh, Nalchigar and Jamporazmey, 2010, p.5932).

The most prominent benefit of balanced scorecard is that it makes it easier to implement the strategy for every employee, from the lowest level to the highest level (Olve et al., 2004, p.2). What is essentially expected from the balanced scorecard is that it may function as a promoter to develop a strategy and to determine corporative objectives (Çukurcayır and Eroğlu, 2004, p.41). Briefly stated, the balanced scorecard is an integral part of the strategic planning process (Ho, Cheng and Lin, 2001, p.20).

Corporate performance is a multidimensional structure. Satisfying only the interests and expectations of partners and shareholders in this structure is not enough for the future of the company in today's world; employees and customers should also be satisfied at the same time (Ağca and Tuncer, 2006, p.191). Accordingly, balanced scorecard completes traditional financial perspectives with three non-financial performance perspectives. These performance perspectives are customer, internal business processes, and learning-growth (Kaplan and Norton, 1996a, 1996b). Financial and customer 
perspectives define what the organization strives to accomplish, while internal business processes and learning-growth perspectives encompass how to implement the strategy (Kaplan and Norton, 2004, p.12).

Kaplan and Norton (1996b, p.165) emphasize that the number of the criteria used in a balanced scorecard should be between 15 and 25 . When developing a balanced scorecard, it is often very complicated and challenging to operationally and objectively determine the non-financial criteria to be used in the balanced scorecard (Alles and Gupta, 2002, p.236). Person (2009, pp.74-75) states that it would cause confusion if there exist more than 20 criteria.

In this paper, we examine the insurance companies' (in Turkey) opinions regarding balanced scorecard and performance techniques. Then, we investigate which perspectives and criteria are used by insurance companies and finally we create a table of balanced scorecard hierarchy. This hierarchy indicates the weights of the perspectives and the criteria.

The organization of this study is as follows. In section 2 we give an overview of the literature. In Section 3 , the data and methodology are introduced. In next section, we evaluate findings. Finally, in Section 5, we give a conclusion.

\section{LITERATURE REVIEW}

Following is a brief summary of literature regarding sectors that implement balanced scorecard: Telecommunication, media, food and beverage sector, oil, metal and engineering sector (Malmi, 2001), retail sector (Agca and Tuncer, 2006), supply chain sector (Bhagwat and Sharma, 2007), hospitality (Kilinc, Mesci and Guler, 2008), information technology sector (Lee, Chen and Chang, 2008), R\&D (Eliat, Golay and Shtub, 2008), insurance sector (Ak and Oztaysi, 2009), aviation industry (Gencer and Cetin, 2011), forage sector (Uygur, aso2009), manufacturing sector (Yuksel and Dagdeviren, 2010), ecommerce (Asosheh et al., 2010), banking sector (Al-mawali, Zainuddin and Ali, 2010), public research organizations (Sartorius, Trollip and Eitzen, 2010). In addition, below are presented some sector practices:

Rockwater Company, one of Brown Root Energy's divisions, was an oil and gas producer company. The company began to use balanced scorecard along with new strategies in 1993 while they were losing money in 1992. By 1996, Rockwater had grown and increased its profitability in the sector (Kaplan and Norton, 2001, p.6).

In 1994, Mobil Corporation's Marketing and Refining Group (Mobil) implemented balanced scorecard. Despite being the last in ranking in its sector, the company rose to the top by growth in profitability, as a result of their implementation of the balanced scorecard (Wisner, 2010, p.4).

CIGNA Property \& Casualty Insurance deployed a new strategy in 1994, using the Balanced Scorecard, increased its profitability within two years, and exhibited top quartile performance in 1998 even though it was the worst insurance company in the industry, near bankruptcy in 1993 (Kaplan and Norton, 2001, p5).

AT\&T Canada, Inc. could not provide employee satisfaction and was close to defaulting on its debts in 1995 . Therefore, the management developed balanced scorecard system. By the end of 1998, the firm achieved positive cash flow (Kaplan and Norton, 2001, p.18).

Additionally, a survey research focusing on "Management Tools and Techniques" was carried out by Bain \& Company in 1999, 2002 and 2006. Findings of the research conducted in 1999 suggested that 43,9\% of 214 companies in North America used balanced scorecard (Rigby, 2001). According to the findings of another study, conducted in 2002, however, indicated $68 \%$ of 708 businesses used balanced scorecard system (Rigby, 2003). Research in 2006 concluded that $70 \%$ of customers reported that they were using balanced scorecards and satisfaction levels emerged to be 3.5/5.0 (Person, 2009).

Media General is a media organization operating in America for more than 150 years. It could not achieve systematic growth and experienced challenges in competition until the 1990s. In 1990, it began to implement balanced scorecard management system. By 2002, however, it was realized $4 \%$ growth and the organization was the 'runner up' in the field of publication, among its competing organizations (Kaplan and Norton, 2006).

Findings of a survey research conducted in 140 companies in USA [banks $(33,3 \%)$, insurance companies $(21,4 \%)$, other financial institutions $(45,3 \%)$ ] at the end of 1999 revealed that $20 \%$ of the companies used balanced scorecard, $10,7 \%$ were in the pipeline to implement balanced scorecard system, and $17,1 \%$ considered to implement balanced scorecard. In addition, it was concluded that $50,7 \%$ did not even think to start using balanced scorecard and $1,4 \%$ used balanced scorecard for a certain period and quitted (Ittner, Larcker and Randall, 2003).

In another study was administered a questionnaire on balanced scorecard in 201 firms (100 German, 50 Swiss and 51 Austrian firms). 174 firms ( 89 German, 42 Swiss and 43 Austrian firms) participated in the survey. The findings suggest that 68 firms use balanced scorecard, 32 firms know about balanced scorecard, 44 firms are not interested in balanced scorecard, and 30 firms have used but quitted balanced scorecard (Speckbacher, Bischof and Pfeiffer, 2003, pp.368-370). 
At the end of 2004, Istanbul Chamber of Industry applied a survey to enterprises in their report entitled 'Turkey's Top 500 Industrial Enterprises' and 107 companies responded. According to the results, about one-fifth of the enterprises (18,69\%) used balanced scorecard, 2,80 \% reported they would start implementing balanced scorecard in the short run and 0,93\% used balanced scorecard for a certain period while a majority of $59,81 \%$ never used balanced scorecard (Coskun, 2005).

\section{DATA AND METHODOLOGY}

A questionnaire was primarily prepared to determine future targets and to identify sub-criteria to be used for four perspectives of balanced scorecard (Financial perspectives, customer perspectives, internal business processes perspectives and learning-growth perspectives). The criteria used in the questionnaire were selected out of the most widely used ones in the literature. After including the criteria, the questionnaire form was sent to the Association of the Insurance and Reinsurance Companies in Turkey. 41 experts responded to the questionnaire they were delivered. The participants favored four criteria, which they considered to be prominent and significant for their companies, from the list. Thirty-nine forms $(95,2 \%)$, excluding two forms $(4,8 \%)$ regarded invalid, were used for the analysis. SPSS v.13 was utilized for the analyses.

In accordance with the data obtained, four most widely used criteria were identified. Another survey including items regarding performance criteria, performance measurement and balanced scorecard was constructed for the research. Survey forms were administered via Adana Regional Offices.

The Association of the Insurance and Reinsurance Companies has 58 members. These members are operating in life, nonlife and pension branches. Performance criteria used by the pension companies differ from what other companies prefer. In this regard, pension companies were excluded and surveys were sent to the forty-three companies remaining. 30 of them responded to surveys.

The data about performance measurement and balanced scorecard were analyzed by using SPSS v.13. However; data about performance criteria and performance measurements were analyzed by using Expert Choice 11 . Expert Choice 11 is a packaged software used in the Analytical Hierarchy Process (AHP). AHP is one of the multi-criteria decision-making techniques. In AHP, the geometric mean is used in pairwise comparisons since two or more evaluations are included. We have thirty evaluations in our sample. Accordingly, in our study, the geometric mean of thirty companies is analyzed by Expert Choice 11.

\section{FINDINGS AND DISCUSSIONS}

Table 1 presents participants' overall opinion regarding the performance management. More than half of the participants $(53,4 \%)$ consider corporate performance measurement as 'the most important activity of management control function.' $50 \%$ of the participants agree that corporate performance measurement increases competitive advantage for their company and $46,7 \%$ strongly agree that corporate performance measurement must be done for all divisions and branches in the organization. Nearly half of the participants $(46,7 \%)$ suggest that corporate performance measurement must be replicated consistently while $53,3 \%$ disagree that only financial measures are enough to realize corporate objectives. $50 \%$ report that it is additionally required to make use of non-financial measures to succeed.

Table 1: The Opinions Regarding the Performance Measurement (\%)

\begin{tabular}{|c|c|c|c|c|c|c|}
\hline No. & Items & 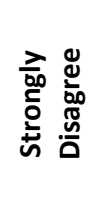 & $\begin{array}{l}\stackrel{ \pm}{d} \\
\frac{10}{00} \\
\stackrel{\mathscr{D}}{0}\end{array}$ & 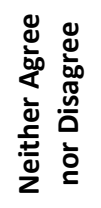 & $\stackrel{\Xi}{\frac{1}{40}}$ & 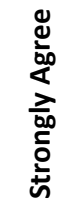 \\
\hline & & $\%$ & $\%$ & $\%$ & $\%$ & $\%$ \\
\hline 1 & $\begin{array}{l}\text { Corporate performance measurement is the most } \\
\text { significant activity of the management's control } \\
\text { function. }\end{array}$ & 6,7 & 3,3 & 3,3 & 53,4 & 33,3 \\
\hline 2 & $\begin{array}{l}\text { Corporate performance measurement increases } \\
\text { competitive edge for the company }\end{array}$ & 6,7 & - & 10,00 & 50,00 & 33,3 \\
\hline 3 & $\begin{array}{l}\text { Corporate performance measurement must be done } \\
\text { for the entire company }\end{array}$ & 3,3 & 10,0 & - & 40,00 & 46,7 \\
\hline 4 & $\begin{array}{l}\text { Corporate performance measurement must be done } \\
\text { consistently }\end{array}$ & 3,3 & 10,00 & 6,7 & 33,3 & 46,7 \\
\hline
\end{tabular}


5

Only financial measurement is enough to succeed.

It is essential to make use of non-financial measures to succeed.
$26,7 \quad 53,3$

6,7

13,3

6,7

50,00

43,3

Table 2 provides the distribution of the companies regarding the use of balanced scorecard system. Twenty companies report that they are currently using balanced scorecard while ten companies do not. Those companies, which they do not make use of balanced scorecard system, were asked whether they plan or intend to use balanced scorecard in the future; six companies have positive responses while four others have negative.

Table 2: The Number of Companies Using Balanced Scorecards

\begin{tabular}{llllc}
\hline Items & & $\mathbf{N}$ & $\%$ \\
\hline We use balanced scorecard in our company. & No & 10 & 33,3 \\
& Yes & 20 & 66,7 \\
\cline { 2 - 4 } & Total & 30 & 100,0 \\
\hline $\begin{array}{l}\text { We intend to make use of balanced } \\
\text { scorecard in our company. }\end{array}$ & No & 4 & 40,0 \\
& Yes & 6 & 60,0 \\
\cline { 2 - 4 } & Total & 10 & 100,0 \\
\hline
\end{tabular}

Table 3 displays findings regarding the performance measurement techniques preferred and used by the companies which do not use balanced scorecard. It is observed in the table that the majority of companies (70\%) report they currently use productivity analysis. $50 \%$ have internal analysis technique, $30 \%$ have Data Envelopment Analysis and only $20 \%$ use External Analysis Technique for performance measurement. These findings suggest that the productivity analysis is the most commonly used measurement technique of all.

Table 3: Performance Measurement Techniques Used by Companies

\begin{tabular}{lll}
\hline Performance Measurement Techniques & Yes & No \\
\cline { 2 - 3 } & $\%$ & $\%$ \\
\hline Productivity Analysis & 70 & 30 \\
Internal Analysis Technique & 50 & 50 \\
External Analysis Technique & 20 & 80 \\
Data Envelopment Analysis & 30 & 70 \\
\hline
\end{tabular}

Table 4 summarizes findings regarding the time period to use balanced scorecard As previously stated, twenty companies reported they used balanced scorecard. Balanced scorecard has been used by those companies for at least 4 months to 144 months (12 years). 11 companies (55\%) have been using balanced scorecard for more than a year while 9 companies have less than a one-year period in experiencing balanced scorecard in performance measurement.

Table 4: Findings Regarding the Time Period to Use Balanced Scorecard

\begin{tabular}{lllc}
\hline Duration & & $\mathbf{N}$ & $\%$ \\
\hline Less than a year & 4 months & 1 & 5,0 \\
& 6 months & 2 & 10,0 \\
8 months & 2 & 10,0 \\
10 months & 1 & 5,0 \\
& 12 months & 3 & 15,0 \\
\cline { 2 - 4 } & Total & 9 & 45,0 \\
\hline More than a year & 2 years & 2 & 10,0 \\
& 5 years & 2 & 10,0 \\
\hline
\end{tabular}




\begin{tabular}{lcc}
8 years & 2 & 10,0 \\
10 years & 4 & 20,0 \\
12 years & 1 & 5,0 \\
\hline Total & 11 & 55,0 \\
\hline
\end{tabular}

Table 5 summarizes perspectives used on the balanced scorecard by the companies. In addition to four perspectives, 'Competence', used by two companies, appears to be the fifth perspective.

Table 5: Perspectives Used on the Balanced Scorecard

\begin{tabular}{|c|c|c|c|}
\hline Dimensions & & Yes & No \\
\hline \multirow[t]{2}{*}{ Financial Perspectives } & $\mathrm{N}$ & 18 & 2 \\
\hline & $\%$ & $\% 90$ & $\% 10$ \\
\hline \multirow[t]{2}{*}{ Customer Perspectives } & $\mathrm{N}$ & 18 & 2 \\
\hline & $\%$ & $\% 90$ & $\% 10$ \\
\hline \multirow[t]{2}{*}{$\begin{array}{lll}\text { Internal } & \text { Business } & \text { Processes } \\
\text { Perspectives } & & \end{array}$} & $\mathrm{N}$ & 20 & 0 \\
\hline & $\%$ & $\% 100$ & 0 \\
\hline \multirow[t]{2}{*}{ Learning and Growth Perspectives } & $\mathrm{N}$ & 18 & 2 \\
\hline & $\%$ & $(\% 90)$ & $\% 10$ \\
\hline \multirow[t]{2}{*}{ Competence Perspectives } & $\mathrm{N}$ & 2 & 18 \\
\hline & $\%$ & $\% 25$ & $\% 75$ \\
\hline
\end{tabular}

As observed in Table 6, 35\% strongly agree that balanced scorecard is the most important tool of management accounting. Companies consider balanced scorecard as an effective asset for measurement. 50\%, however, report that they strongly agree to regard balanced scorecard as an integral part of the strategic planning process as only $5 \%$ has a negative response. $85 \%$ think that balanced scorecard will increase their comparative edge. $95 \%$ have a consensus and emphasize that balanced scorecard must be valid and implemented consistently for the entire company. However; with respect to the negative reflection of the balanced scorecard on employees, $40 \%$ report negative responses meaning that balanced scorecard do not cause employees to push actual work into the background in order to achieve the targets set. Besides, a total of $55 \%$ disagrees with the item that the perspectives are subjectively evaluated. However, $40 \%$ of the participants agree that non-financial measures are difficult to measure in balanced scorecard.

Table 6: Companies' Opinions about Balanced Scorecard

\begin{tabular}{|c|c|c|c|c|c|c|}
\hline No. & Items & 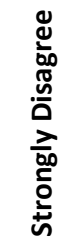 & 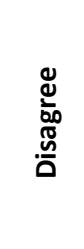 & 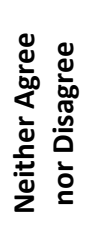 & 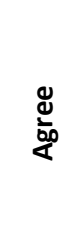 & 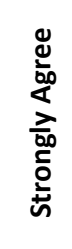 \\
\hline & & $\%$ & $\%$ & $\%$ & $\%$ & $\%$ \\
\hline 1 & $\begin{array}{l}\text { Balanced Scorecard is the most important tool of management } \\
\text { accounting. }\end{array}$ & 5,0 & 5,0 & 15,0 & 40,0 & 35,0 \\
\hline 2 & Balanced Scorecard is an integral part of strategic planning process. & 5,0 & - & - & 45,0 & 50,0 \\
\hline 3 & Balanced Scorecard provides competitive edge for our company. & 5,0 & - & 10,0 & 45,0 & 40,0 \\
\hline 4 & Balanced Scorecard must be done for the whole company. & - & 5,0 & - & 40,0 & 55,0 \\
\hline
\end{tabular}




\begin{tabular}{cllllll}
\hline 5 & $\begin{array}{l}\text { Balanced Scorecard cause employees to push their actual workload } \\
\text { into the background in order to achieve the targets set. }\end{array}$ & 20,0 & 40,0 & 35,0 & 5,0 & - \\
\hline 6 & $\begin{array}{l}\text { While determining balanced scorecard, it comes into question that } \\
\text { the perspectives are subjectively evaluated. }\end{array}$ & 25,0 & 30,0 & 15,0 & 25,5 & 5,0 \\
\hline 7 & $\begin{array}{l}\text { Non-financial criteria are difficult to measure in Balanced } \\
\text { Scorecard. }\end{array}$ & 20,0 & 25,0 & 5,0 & 40,0 & 10,0 \\
\hline
\end{tabular}

The Figure 1 summarizes the hierarchy of balanced scorecard. There are objective, perspectives and criteria in this hierarchy chart. Each value in parentheses indicates the weights of the criteria in each group.

Figure 1: Hierarchy of Balanced Scorecard

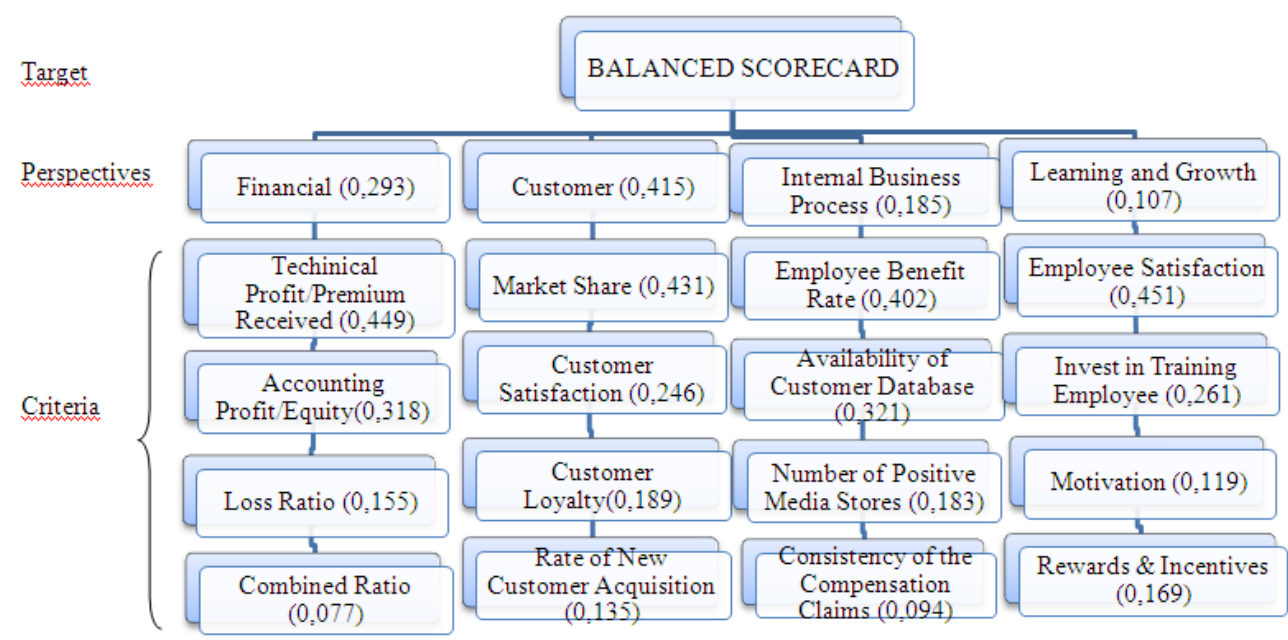

\section{CONCLUSION}

Research focusing on the construction and detailed implementation of balanced scorecard in the financial sector are not often encountered in the literature. In this study were identified the criteria used by the insurance companies operating in Turkey in balanced scorecard. As a result, insurance companies can make use of these criteria. Thus, companies may improve their performance and work more effectively by elaborating the criteria which reduce their performance.

In this way, as they improve their performance, they can contribute to the economy, especially the finance sector. In conclusion, this paper contributes to the literature and provides insights and implications to help those who want to implement balanced scorecards in insurance companies.

\section{REFERENCES}

Ağca, V., and Tunçer, E. (2006). Çok boyutlu performans değerleme modelleri ve bir balanced scorecard uygulaması. Afyon Kocatepe Üniversitesi i.i.B.F. Dergisi. 8: 173-193.

Ahn, H. (2001). Applying the balanced scorecard concept: an experience report, Long Range Planning, 34: 441-461.

Ak, R. and Öztayşi, B. (2009). Performance measurement of insurance companies by using balanced scorecard and anp. $10^{\text {th }}$ International Symposium on the Analytic Hierarchy Process, ISAHP July 29- August 1, Pittsburgh, USA

Akal, Z. (2000). Iş̧letmelerde performans ölçüm ve denetimi çok yönlü performans göstergeleri. 4 Baskı Ankara: Ankara Milli Prodüktivite Yayınları

Alles, M. and Gupta, M. (2002). The impact of uncertainty and ambiguity when implementing the balanced scorecard, Asia-Pacific Journal of Accounting \& Economics, 9 (2): 235-262.

Al-mawali, H.H., Zainuddin, Y., and Ali, N.N.K. (2010). Balanced scorecard (bsc) usage and financial performance of branches in Jordanian banking industry, World Academy of Science, Engineering and Technology, 66: 1722-1729. 
Asosheh, A., Nalchigar, S., and Jamporazmey, M. (2010). Information technology project evaluation: a integrated data envelopment analysis and balanced scorecard approach, Expert Systems with Applications, 37: 5931-5938.

Bayrakdaroğlu, A., and Ege, İ. (2007). Performans ölçümünde alternatif bir yöntem, yatırımın nakit kârlılığı (CFROI) ve halka açık turizm şirketleri üzerine bir uygulama, VI. Anadolu Işsletmecilik Kongresi. Kırıkkale. 94-108.

Bhagwat, R., and Sharma, M.K. (2007). Performance measurement of supply chain management: a balanced scorecard approach, Computers\&Industrial Engineering, 53: 43-62

Braam, G.J.M and Nijsen, E.J. (2004). Performance effects of using the balanced scorecard: a note on the dutch experience, Long Range Planning, 37: 335-349.

Chytas, P., Glayks, M., and Valiris, G. (2011). A proactive balanced scorecard. International journal of information management. (online] URL:http://www.sciencedirect.com/science/article/pii/S0268401210001908.

Coşkun, A. (2005). İşletmelerde performans yönetimi: bir yönetim muhasebesi aracı olarak performans karnesi. Doktora Tezi. İstanbul Üniversitesi.

Çukurçayır, M.A., and Eroğlu, T. H.(2004). Yerel yönetimlerde yeniden yapılanmaya farklı bir yaklaşım: Verimlilik ve başarı karnesi. Sayıştay Dergisi, Nisan- Haziran, 53, 41- 66.

Davis, S., and Albright, T.(2004). An investigation of the effect of balanced scorecard implementation on financial performance, Management Accounting Research, 15: 135-153.

Eilat, H., Golany, B., ve Shtub A. (2008), R\&D Project evaluation: an integrated DEA and balanced scorecard approach. Omega, 36, $895-912$.

Gencer, C., and Çetin, T. (2011). Kurumsal performans karnesi ve havacılık sektöründe bir uygulama. Savunma Bilimleri Dergisi, 10: 105121.

Ho, I.H., Cheng, T.F., and Lin, C.Y. (2001). The Construction of performance evaluation model for engineering educational systems, International Conference on Engineering Education. Oslo, Norway. Session 6B8.

Ittner, C. D., Larcker, D. F.,and Randall, T. (2003). Performance implications of strategic performance measurement in financial services firms, Accounting, Organizations and Society, 7-8: 715-741

Jing, F. F.,and Avery, G. C (2008). Missing links in understanding the relationship between leadership and organizational performance, International Business \& Economics Research Journal, 7: 67-78.

Kallunki, J.P., and Silvola, Hanna. (2008). The effect of organizational life cycle stage on the use of activity-based costing, Management Accounting Research, 19: 62- 79

Kaplan, R.S. and Norton, D. (2006). Alignment using the balanced scorecard to create corporate synergies.1st Edition. Boston: Harvard Business School Press.

Kaplan, R. S., and Norton D. (2004). Strategy maps converting intangible assets into tangible outcomes. 1st Edition. Boston: Harvard Business School Press.

Kaplan, R. S., and Norton D. (2001). The strategy-focused organization how balanced scorecard companies thrive in the new business environment. 2nd Edition Boston: Harvard Business School Press.

Kaplan, R. S., and Norton, D. P. (1996b). Translating strategy into action balanced scorecard. 1st Edition. Boston: Harvard Business School Press

Kaplan, R. S., and Norton, D. P. (1996a). Using the balanced scorecard as a strategic management system, Harvard Business Review, 74: 7585.

Kaplan, R. S., and Norton, D. P. (1992). The balanced scorecard: measures that drive performance, Harvard Business Review, 70: 71-79.

Kılınç, İ., Mesci, M., and Güler Y. (2008). Dengeli ölçüm kartının (balanced scorecard) Alanya'daki dört ve beş yıldızlı otel işletmelerinde uygulanabilirliliğine yönelik bir araştırma. Dumlupınar Üniversitesi Sosyal Bilimler Dergisi, 22: 155-177.

Lee, A.H.I., Chen, W. C., and Chang, C.J. (2008). A fuzzy ahp and bsc approach for evaluating performance of it department in the manufacturing industry in Taiwan, Expert Systems with Applications, 34: 96-107.

Malmi, T. (2001). Balanced scorecards in Finnish companies: a research note, Management Accounting Research, 12, $207-220$.

Leung, L.C., Lam, K.C., and Cao, D. (2006). Implementing the balanced scorecard using the analytic hierarchy process\& the analytic network process, The Journal of Operational Research Society, 57: 682-691.

Metawie, M. and Gilman, M. (2005). Problems with the Implementation of performance measurement systems in the public sector where performance is linked to pay: a literature review drawn from the UK, $3^{\text {rd }}$ Conference on Performance Measurements and Management Control, Nice. 1-24.

Olve, N. G., Petri, C. J., Roy, J., and Roy, S. (2004). Twelve years later: understanding and realizing the value of balanced scorecards, Ivey Business Journey, 5-6: 1-7. 
Person, R. (2009). Balanced scorecards and operational dashboards with Microsoft excel. 1st Edition. Wiley Publishing, Indianapolis Rigby, D. (2003). Management tools 2003. [online] URL: www.bain.com.

Rigby, D. (2001). Management tools and techniques: a survey. California Management Review, 43: 139-160.

Speckbacher, G., Bischof, J. and Pfeiffer T. (2003). A descriptive analysis on the implementation of balanced scorecards in German-speaking countries, Management Accounting Research, 14: 361-387.

Sartorius, K., Trollip, N. and Eitzen, C. (2010). Performance measurement frameworks in a state controlled research organization: can the balanced scorecard (bsc) be modified?, South African Journal of Business Management, 41(2): 51-63.

Utkutuğ, Ç.P. (2008). Kurumsal performans yöntemi olarak toplam başarı göstergesi yöntemi, Endüstriyel Sanatlar Eğitim Fakültesi Dergisi 23: $55-78$.

Uygur, A. (2009). Çok boyutlu performans değerleme modeli olarak dengeli başarı göstergesi uygulaması. Doğuş Üniversitesi Dergisi, 10: 148-159.

Wisner, P. (2010) Multidimensional performance measurement using the balanced scorecard. [online] URL:Www.qfinance.com.

Yenice, E. (2007). Performans ölçümünde karşılaşılan sorunlar ve kurumsal karne (balanced scorecard) yaklaşımı, Bütçe Dünyası, 2: 95100.

Yüksel, İ., and Dağdeviren, M. (2010). Using the analytic network process (Anp) for balanced scorecard (Bsc): A case study for a manufacturing firm, Expert Systems with Applications, 37: 1270-1278. 